\title{
VEGF expression in pancreatic cancer and other malignancies: a review of the literature
}

\author{
M.I. COSTACHE ${ }^{1,2}$, MIHAI IOANA ${ }^{1,3}$, SEVASTIȚA IORDACHE ${ }^{1}$, D. ENE ${ }^{5,6}$, \\ CORNELIA ALEXANDRA COSTACHE ${ }^{7}$, A. SĂFTOIU ${ }^{1,4}$ \\ ${ }^{1}$ Gastroenterology Research Center of Gastroenterology and Hepatology, \\ University of Medicine and Pharmacy Craiova, Romania \\ ${ }^{2}$ Radiology Department, University Hospital, Craiova, Romania \\ ${ }^{3}$ Nijmegen Institute for Infection, Inflammation and Immunity (N4i), \\ Radboud University Nijmegen Medical Centre, Nijmegen, The Netherlands \\ ${ }^{4}$ Gastrointestinal Unit, Copenhagen University Hospital Herlev, Denmark \\ 5"Carol Davila" University of Medicine and Pharmacy, Bucharest, Romania \\ ${ }^{6}$ Surgery I Department, Floreasca Hospital, Bucharest, Romania \\ ${ }^{7}$ Neurology Department, Neuropsychiatry Hospital, Craiova, Romania
}

\begin{abstract}
Angiogenesis is a crucial event for tumor growth and it is regulated predominantly by several different growth factors. Vascular endothelial growth factor protein family (VEGF) and its receptors are probably the most important tissue factors responsible for angioblast differentiation and tube formation. VEGF protein family currently comprises several members: VEGF (or VEGF-A), VEGF-B, VEGF-C and VEGF-D, VEGF-F, placental growth factor (PlGF), and their receptors VEGFR-1, VEGFR-2 and VEGFR-3. VEGF is a key angiogenic growth factor and its level of expression is a critical marker for detection of the angiogenic diseases. The potent role of VEGF in tumor angiogenesis has been widely described in the past decade, being expressed in most types of nondigestive and digestive cancers. VEGF family members play an important role in the development of pancreatic cancer (especially VEGF-A, VEGF-C, VEGF-D, VEGFR-1 and VEGFR-2). VEGF-A is the most specific and prominent angiogenic factor among all family members and VEGFR-2 is the most important receptor in evaluating the angiogenesis in pancreatic cancer. Thus, VEGF overexpression may be considered as a diagnostic marker and as a poor prognostic factor of the disease.
\end{abstract}

Key words: Angiogenesis, VEGF, pancreatic cancer.

\section{INTRODUCTION}

All human cells need oxygen and nutrients to survive and to ensure proper growth and differentiation. Thus, the formation of the vascular system (vasculogenesis) by the differentiation of endothelial cell precursors [1] is crucial to provide efficient blood supply and organ specific vascular functions [2]. This system needs to be maintained through angiogenesis, the process which summarizes a set of morphogenic events that expand and fine-tune the initial, more primitive, embryonic vascular network of arterioles, venules and highly branched capillaries [3]. The formation of new blood vessels occurs in normal circumstances (during wound healing, organ regeneration, and in the female reproductive system during ovulation, menstruation, and the formation of the placenta), but it is also an important factor in several pathological processes (tumor growth, rheumatoid arthritis, diabetic retinopathy, and psoriasis). Angiogenesis is tightly controlled by a physiological balance between the stimulatory (proangiogenic factors) and inhibitory (antiangiogenic factors) signals for blood vessel growth [1]. Angiogenesis and vasculogenesis are regulated predominantly by several different growth factors and their associated receptor tyrosine kinases: vascular endothelial growth factor (VEGF), fibroblast growth factor (FGF)-2, angiopoietins (Angs), transforming growth factor (TGF)- $\beta$, netrins, semaphorins, ephrin, Notch, survivin [4]. Probably, the most important tissue factors responsible for angioblast differentiation and tube formation are $\boldsymbol{V E G F}$ (vascular endothelial growth factor) protein family and VEGFRs (VEGF receptors). Established as the prime angiogenic molecule during organogenesis, as well as post-natal physiological and pathological angiogenesis, VEGF is the most potent stimulator 
of endothelial cell proliferation, sprouting, migration and tube formation and is also a powerful survival factor and permeability factor for endothelial cells [2].

\section{VEGF PROTEIN FAMILY AND ITS RECEPTORS}

Described for the first time in 1989 [5], the VEGF protein family currently comprises several members: VEGF (or VEGF-A), VEGF-B, VEGF-C and VEGF-D , VEGF-F, placental growth factor (PIGF), and their receptors VEGFR-1, VEGFR-2 and VEGFR-3 [6].

VEGF-A is a dimeric glycoprotein essential for many angiogenic processes in normal and abnormal states [4], being the most specific and prominent angiogenic factor among all VEGF family members [7]. It exists in at least nine homodimeric isoforms (with 121, 145, 148, 162, $165,165 \mathrm{~b} 183,189$, or 206 amino acids) [8]. In normal tissues, the highest levels of VEGF-A mRNA are found in adult lung, kidney, heart, and adrenal gland $[1,9,10]$. VEGF-A has the capacity to stimulate vascular endothelial cell proliferation and the ability to increase vascular permeability [11-14]. It also promotes the survival and migration of endothelial cells [4]. VEGF-A has become a center of interest due to its important role in physiological and pathological processes such as embryonic development, wound healing, female reproductive cycle, cancer, cardiovascular disease, etc. $[15,7]$. Discovered in 1995, VEGF-B has a wide tissue distribution, but is abundantly expressed in the adult myocardium, skeletal muscle, and pancreas [16]. In adult tissues, VEGF-C is expressed most prominently in the heart, placenta, ovary, small intestine, and the thyroid gland [1]. It is the paracrine factor essential for lymphangiogenesis [4]. VEGF-D is found in adult tissues, particularly the lung, heart, skeletal muscle, colon, and small intestine [1, $17,18]$.

Three VEGF tyrosine kinase receptors have been identified: VEGFR-1, VEGFR-2 and VEGFR-3 [17]. VEGFR-1 (The fms-like tyrosine kinase, Flt-1) and VEGFR-2 (the kinase domain region also referred to as fetal liver kinase, KDR/Flk-1) are expressed predominantly by vascular endothelial cells. They are present in tumor cells, where they are coexpressed with VEGF, and they are also expressed by smooth muscle cells, pancreatic beta cells, and osteoblasts [17]. But theVEGFR-2 is the major mediator of the mitogenic, angiogenic and permeability-enhancing effects of VEGFA. Furthermore, recent studies have indicated that the activation of VEGFR-2 also promotes lymphangiogenesis [19]. VEGFR-3 (Flt-4) is generally restricted to lymphatic endothelial cells, activation stimulates mitosis, migration, differentiation, and survival of these cells, being up-regulated in lymphangiogenic vessels, but not in angiogenic vessels [20]. VEGFR2 is abundant in the tip cells of angiogenic sprouts, where VEGF/VEGFR2 functions upstream of the delta-like ligand 4 (DLL4)/Notch signal transduction pathway. VEGFR3 is expressed in all endothelia and is indispensable for angiogenesis during early embryonic development. In adults, VEGFR3 is expressed in angiogenic blood vessels and some fenestrated endothelia. VEGFR2 is required independently of VEGFR3 for endothelial DLL4 up-regulation and angiogenic sprouting, and for VEGFR3 functions in angiogenesis [21].

\section{VEGF EXPRESSION IN CANCER}

VEGF is a key angiogenic growth factor and its level of expression is a critical marker for detection of the angiogenic diseases. The increase or decrease of angiogenesis is related to various diseases in different stages of life. Thus, we find a high level of VEGF expression in the diseases which show an increase in angiogenesis like cancers, atherosclerosis, haemangiona, diseases of the skin and mucosae, retinopathy, liver and kidney disease, inflammatory diseases. They are the pathological states which show reduction in angiogenesis where the expression of VEGF is low: ischemic disease, bone disorders, leukoencephalopathy, diseases of the brain, coronary artery disease, peripheral vascular disease [7]. The neovascularization of solid tumors facilitates their growth and metastasis by providing nutrient flow. The new blood vessels result by the proliferation and migration of endothelial cells from existing vasculature supplying the tumor bed in a complex process that involves the regulated interaction of several soluble mediators and their cognate receptors. The potent role of VEGF in tumor angiogenesis has been widely described in the last decade. VEGF is expressed in most 
tumours and its expression correlates with tumour progression [22].

\section{NON-DIGESTIVE CANCERS}

Many meta-analysis and clinical studies demonstrated that VEGF expression and their receptors are implicated in most types of nondigestive cancer. Thus, overexpression of VEGF was found in head and neck cancer [23, 24]. By inducing proliferation of lymphatic endothelia cell and development of lymphatic vessels, VEGF-C and VEGF-D contributed to lymphatic metastasis of papillary thyroid carcinoma [25]. VEGF has important effects on the occurrence, development, and metastasis in non-small cell lung cancer (NSCLC) patients, which could be applied as the indicators to predict the malignancy and prognosis of this type of cancer [26-28]. VEGF-C expression is associated with poor prognosis for these patients, including patients with stage I NSCLC [29]. VEGFR-1 and VEGF expressions were significantly increased in breast cancer in relation to surrounding tissue and the VEGF expression was significantly increased in lymph node positive breast cancer patients [30]. VEGF could impact ovarian cancer's malignant progression [31]. VEGFR2 is significantly related to ovarian metastasis and invasion [32]. TheVEGF-receptor status as a molecular biomarker for monitoring tumor cell spread to the bone marrow and, particularly, revealing prognostic significance of VEGF-R1 [33]. VEGF is an important proangiogenic factor in neoangiogenesis in precancerous and cancerous changes in the cervix [34]. Detection of VEGF-C mRNA has clinical potential as a predictor for identifying patients with $\mathrm{pN} 0$ cervical cancer at high risk of lymph node recurrence and poor prognosis [35]. An increased expression of VEGF-A, VEGFR2 and VEGFR-3 was seen in endometrial cancers compared with normal endometrium. VEGFR3 was significantly correlated with tumor stage, with a trend towards poorer disease free survival [36]. VEGF expression has an important impact on overall survival in patients with osteosarcoma and high VEGF expression is associated with poorer overall survival $[37,38]$. Activation of VEGFR-1 by VEGF-A within the carcinoma, and activation of lymphatic endothelial cell VEGFR-3 by VEGF-D within the adjacent benign stroma may be important signaling mechanisms involved in the progression and subsequent metastatic spread of prostate cancer [39]. Alterations in the expression of VEGF and VEGF receptors are associated with disease stage and recurrence in bladder cancer patients [40]. VEGF expression may be strongly correlated with pathological characteristics of diffuse large B cell lymphoma (DLBCL) [41]. VEGF plays a significant role in the pathogenesis and tumor angiogenesis of ocular adnexal lymphoma [42]. Both VEGFR-2 and VEGFR-3 can serve as markers for prognosis of papillary renal cell carcinoma. Differently, VEGFR-3 is a predictor of lymph node metastasis, increased VEGFR-2 expression could be used to predict a potential blood dissemination [43].

\section{DIGESTIVE CANCERS}

In the field of gastroenterology, VEGF family expression has been extensively studied.

\section{Gingival and oral cancer}

A meta-analysis of 17 studies that evaluated the correlation between VEGF overexpression detected by immunohistochemistry and survival in patients with oral cancer demonstrated that VEGF overexpression had an unfavorable impact on overall and disease-free survival in patients with oral cancer. VEGF overexpression indicates a poor prognosis for patients with oral squamous cell carcinoma (OSCC), adenoid cystic carcinoma and mucoepidermoid carcinoma of the salivary glands [44]. The VEGF-C may be a predictive factor for oral squamous cell carcinoma cancer outcome, lymph node metastasis, and recurrence. Moreover, VEGF-C may be an important factor in the development of new therapies for OSCC patients [45]. The serum VEGF level may be a reliable biomarker and may be a potential target for development of chemopreventive and chemotherapeutic strategies for patients with tobaccorelated oral carcinoma [46]. The increased expression of VEGF was positively correlated to recurrence and lymph node metastasis in gingival cancer [47].

\section{Esophageal cancer}

Lymph node metastasis is one of the most important prognostic factors in esophageal squamous cell carcinoma (ESCC). Positive expression of VEGF-C was found to correlate significantly with depth of tumor invasion, lymphatic invasion and lymph node [48]. Both VEGF-C and VEGF-D are highly expressed in esophageal squamous cell cancer tissue, which may be related to the lymph 
node metastasis of cancer cells. Hence, VEGF-C and VEGF-D can be clinically considered as important reference indexes of lymph node metastasis [49]. Moreover, the expression of VEGF-C was positively correlated with tumor status and poor clinical prognosis [50]. There was also a significantly increased risk for patients with VEGF overexpression to have an advanced stage of the disease (III and IV). Additionally, patients with VEGF overexpression had a 2.03-fold increased risk for distant metastasis and shorter overall survival [51]. In resectable esophageal squamous cell carcinoma patients, the expression of VEGF is a predictor of distant metastasis, overall survival, and distant metastasis-free survival. Using a combination of VEGF expression, tumor stages, and tumor cell grade, identification of patients with increased risk of postoperative metastases may become possible [52].

\section{Gastric cancer}

It was demonstrated the importance of angiogenetic factors in serum and tumor tissue in gastric cancer for prognosis and treatment response [53]. Increased expression of VEGF-C may play a significant role in the carcinogenesis and progression of gastric adenocarcinoma [54]. Moreover, VEGF$\mathrm{C}$ overexpression indicates a poor prognosis for overall survival at patients with gastric cancer [55]. VEGF-A andVEGF-D are also unfavorable indicators of overall survival and disease free survivalin patients with gastric cancer [56, 57].

\section{Colorectal cancer}

In colorectal cancer, the VEGF expression significantly correlated with advanced stage, unfavorable survival and an increase in the rate of invasion and distant metastases [58, 59]. Over expression of VEGFA has been associated with a high TNM stage, the degree of cell differentiation and patient death as a result of disease being a prognostic molecular biomarker for patients with resected colorectal cancer liver metastasis $[60,61]$. The expression VEGF-C serves also as a significant index for evaluating the degree of malignancy, clinical stages, lymph nodes, and distant metastasis of colorectal adenocarcinoma [62,63].

\section{Liver cancer}

VEGF-C overexpression and VEGF-C gene polymorphisms are associated with susceptibility to hepatocellular carcinoma. It might be a predictive factor for advanced-stage disease [64]. VEGF-A is highly expressed in gallbladder carcinoma and correlates with poor prognosis, suggesting that VEGF-A expression could be used as a biomarker for predicting malignant behavior and for identifying a subset of patients who may benefit from antiVEGF-A therapies [65]. VEGF-D plays, also, an important role in gallbladder cancer progression [66].

\section{Pancreatic cancer}

Many studies in literature show the importance of VEGF proteins family and their receptors in pancreatic tumors. Most of these evaluate the expression of VEGF using postoperative samples and mice models or the level of VEGF in blood or bile.

The pancreatic endocrine tumor is the first human tumor entity in which VEGF-C-related intratumoral lymphangiogenesis has been demonstrated. The upregulation of VEGF-C may be involved in the progression and metastases. Examination of the VEGF-C-specific receptors VEGFR-2 and VEGFR-3 demonstrated intense endothelial immunoreactivity for VEGFR-2, as well as VEGFR-2 and VEGFR-3 expression on the majority of neoplastic cells, suggesting a possible role in autocrine/paracrine neoplastic growth regulation $[67,68]$.

Mucinous pancreatic cysts (intraductal papillary mucinous neoplasm and mucinous cystic neoplasm) have the potential to progress to invasive pancreatic adenocarcinoma. VEGF, VEGF-A,VEGF-C, VEGFR2 and VEGFR-3 are overexpressed in these types of tumours. Having a high sensitivity and specificity VEGF-A is a good biomarker for early detection, prevention, and cure for the serous cystic neoplasms of the pancreas [69-71].

VEGF plays an important role in the development of pancreatic cancer [72]. Compared with normal pancreas and chronic pancreatitis, VEGF and its receptors were overexpressed in pancreatic cancer [73]. Seo Y et al. demonstrated that $93 \%$ of ductal pancreatic adenocarcinomas were positive for VEGF protein [74]. A recent study shows a positive expression rate of VEGF $77 \%$ in pancreatic cancer tissues and $15 \%$ in adjacent normal pancreatic tissues [75]. The lymphangiogenesis can be considered an early event that enables the dissemination of metastases. VEGF expression and low lymphatic vessel density 
can be considered as poor prognostic factors as tumors with this profile are fast growing and highly aggressive [76]. VEG Foverexpression was found to be associated with high microvascular density and emerged as adverse prognostic factors in terms of patient survival in pancreatic ductal adenocarcinoma [77]. The expression of VEGF is also significantly correlated with TNM stage and lymph node metastasis. VEGF may play an important role in the occurrence, development, and metastasis of pancreatic cancer [75]. Moreover, multivariate logistic regression analysis indicated a significant association between high VEGF expression and liver metastasis [74]. A recent meta-analysis revealed that the immunohistochemical expression of VEGF representing a significant and reproducible marker of adverse prognosis in resected pancreatic cancer [78], but most consistently reproducible molecular marker with prognostic value in resected pancreatic adenocarcinoma is considered to be the fibroblast activation protein [79]. In vitro, most pancreatic ductal carcinomas show a distinct VEGF related angiogenic potential, as demonstrated by 2- and 3-D endothelial cell proliferation, which may be promoted by severe hypoxia. Surprisingly, perinecrotic tumor areas, which are supposed to be hypoxic, only rarely showed the expected increase in microvessel density and VEGF expression [80]. VEGF- $A$ gene locus analysis across 80 human tumour types reveals VEGF-A gene alterations were predominantly observed in hepatocarcinomas, adenocarcinomas of the pancreas and intestine, large cell carcinoma of the lung and in endometrium serous carcinoma [81]. Immunohistochemical analysis of 50 pancreatic cancer tissue samples revealed the presence of VEGF-A immunoreactivity in $50 \%$ of the cancer tissue samples. The presence of VEGF-A in these cells was associated with larger tumor size and enhanced local spread but it was not associated with decreased patient survival [82]. VEGF-A significantly increased the motility of pancreas cancer cells playing an important role in inducing invasion and migration of pancreatic cancer cells [83]. The prognosis for VEGF-A-positive patients was significantly poor [84]. UICC stage III pancreatic carcinoma patients with VEGF165 (a type of VEGF-A) negative tumor cells had a significantly better outcome after surgery compared to UICC stage III patients with VEGF165-positive tumor cells (median survival time 19 months $v s .9$ months

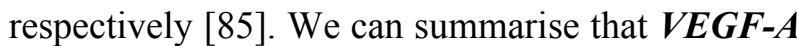
expression is an important predictor for both distant metastasis and poor prognosis in ductal pancreatic adenocarcinoma.

In the cancer samples, $\boldsymbol{V E} \boldsymbol{G} \boldsymbol{F}-\boldsymbol{C}$ mRNA transcript increases approximately 2.2-fold, compared with the normal pancreas. Immunohistochemical analysis confirmed the expression of VEGF-C and its receptor (VEGFR-3) in the cancer cells within the tumor mass. VEGF-C expression was positive in approximately $80 \%$ of pancreatic cancers $[86$, 84]. VEGF-C was abundantly expressed in pancreatic cancer tissue and cell lines and VEGFR-3 was expressed in cancer stromal cells. These results suggest that active lymphangiogenesis is not required for lymphovascular spread of pancreatic cancer. VEGF-C may promote local tumor growth via paracrine signaling to stromal cells expressing VEGFR-3 and support the entry of cancer cells into peritumoral lymphatics [87]. VEGF-C expression was correlated with invasion of lymphatic vessels around the tumor [88]. Moreover, in human pancreatic cancer and nude mice model, the expression of VEGF-C on lymphatic metastasis was higher than in primary tumor [89]. The presence of VEGF-C in the cancer cells was associated with increased lymph node metastasis, but it was not associated with decreased patient survival [86, 82].

$\boldsymbol{V E G F - D}$ plays a pivotal role in stimulating lymphangiogenesis and lymphatic metastasis in human ductal pancreatic cancer [90]. VEGF-D expression was positive in $36 \%$ of pancreatic cancers [84]. VEGF-D expression in tumor cells in the marginal portion of the tumor significantly associated with lymphatic metastasis and prognosis in patients with pancreatic head cancer [91].

Vascular endothelial growth factor receptors are mainly expressed by endothelial cells, but they are also expressed in pancreatic cancer cells. Compared with normal pancreas and chronic pancreatitis, VEGF receptors were overexpressed in pancreatic cancer [73]. VEGF and its 3 principal receptors (VEGFR-1,VEGFR-2 and VEGFR-3) were expressed to varying degrees in tumors of the pancreas. Overexpression of VEGF in tumors may activate tumor cells bearing VEGFR-1 via an autocrine pathway [92]. VEGFR-1 plays a role in tumor progression in pancreatic cancer through the induction of epithelial to mesenchymal transition [93]. VEGFR-1 appears to be expressed ubiquitously in pancreatic carcinoma cell lines, in which it induces signaling and promotes migration and invasion. But, a significant association was 
found between low expression of VEGFR-1 and both poor prognosis and advanced stage, suggesting that tumor expression of this VEGF receptor is a marker of less aggressive disease [94]. Compared to normal human pancreas, cancer tissue showed overexpression of $\boldsymbol{V E G F R - 3 ~ i n ~ c o n j u n c t i o n ~ w i t h ~ a ~}$ high lymphatic vascularization [90]. Nevertheless, VEGFR-2 is the most important receptor in evaluating the angiogenesis in pancreatic cancer. A recent study shows that VEGFR-2 were positive in $69 \%$ of pancreatic cancers. In contrast, VEGFR-1 and VEGFR-3 expression was only observed $12 \%$ and $14 \%$ of pancreatic. VEGFR-2 expression in cancer cells correlates significantly with invasion into the surrounding tissues as well as with poor prognosis of pancreatic cancer. The 5-year survival of patients with VEGFR-2-positive tumors was 0\% in comparison to $21 \%$ for patients with negative tumors. A multivariate analysis showed VEGFR-2 to be an independent predictive factor of prognosis in pancreatic cancer especially at clinical stage IIA [84].

VEGF was also, recently, studied using samples collected by endoscopic ultrasound-guided fine needle aspiration (EUS-FNA). A study of thirty-five patients who had undergone endoscopic ultrasonography followed by EUS-FNA of focal pancreatic masses showed that VEGF and EGFR mRNA expression in EUS-FNA samples may be used as a diagnostic marker associated with invasiveness in patients with pancreatic adenocarcinoma [95].

\section{CONCLUSIONS}

Angiogenesis is a crucial event in tumor growth process. It is regulated predominantly by several different growth factors and their associated receptor tyrosine kinases of which vascular endothelial growth factor is the most potent stimulator of endothelial cell proliferation, sprouting, migration and tube formation and it is also a powerful survival factor and a permeability factor for endothelial cells. In the field of gastroenterology, VEGF family expression has been extensively studied and its expression was correlated with: oral cancer, gingival cancer, esophageal cancer, gastric cancer, colorectal cancer, liver and gallbladder cancer. Many studies in literature show the importance of VEGF proteins family and their receptors in pancreatic tumors. VEGF family members overexpression was correlated with the presence of pancreatic adenocarcinoma, with the increase of the invasion and migration of pancreatic cancer cells, with larger tumor size, with TNM stage and lymph node metastasis, with distant metastasis and the poor prognosis of the disease. Therefore, VEGF represents a novel therapeutic target for this devastating type of cancer.

\begin{abstract}
Acknowledgement. The study was supported by the research grant "Minimal invasive assessment of angiogenesis in pancreatic cancer based on imaging methods and molecular techniques (Angio-PAC)", Ideas programme, 164/2011, National Research Council - UEFISCDI, project number PN-II-ID-PCE-2011-30589 .
\end{abstract}

Conflict of interest. The authors declare no conflict of interest.

Angiogeneza este un eveniment crucial în creşterea şi dezvoltarea tumorală şi este controlată de o serie de factori de creştere. VEGF (factorul de creștere a endoteliului vascular) este, probabil, cel mai important factor tisular, implicat in diferențierea angioblastelor şi în formarea rețelelor vasculare. Familia proteinei VEGF cuprinde in prezent mai mulți membri: VEGF (sau VEGF-A), VEGF-B, $V E G F-C$ şi VEGF-D, VEGF-F, factor de creştere placentar (PlGF) şi receptorii lor VEGFR-1, VEGFR-2 şi VEGFR-3. VEGF este un factor de creştere cheie, iar expresia sa este un marker critic pentru aprecierea bolilor angiogenice. Rolul decisiv al VEGF în angiogeneza tumorală a fost descris pe larg în ultimul deceniu, acesta fiind exprimat în majoritatea tipurilor de cancere non-digestive şi digestive. Membrii familiei VEGF joacă un rol esențial în dezvoltarea cancerului pancreatic (în special VEGF-A, VEGF-C, VEGF-D, VEGFR-1 şi VEGFR-2). Dintre aceştia, nivelurile tisulare ale VEGF-A şi ale VEGFR-2 sunt cele mai specifice şi mai evidente în ceea ce priveşte utilitatea în evaluarea angiogenezei în cancerul pancreatic. Expresia genetică crescută a VEGF poate fi, astfel, considerată un important marker diagnostic dar şi un indice de prognostic nefavorabil al patologiei neoplazice pancreatice.

Corresponding author: Madalin Ionut Costache, 11A Rovinari str., Craiova, Dolj, 200533, Romania

Tel: +40765790960

E-mail: costache_madalin_ionut@yahoo.com 


\section{REFERENCES}

1. HOEBEN A., LANDUYT B., HIGHLEY M.S., WILDIERS H., VAN OOSTEROM A.T., DE BRUIJN E.A. Vascular endothelial growth factor and angiogenesis. Pharmacol Rev. 2004; 56(4):549-580.

2. CRIVELLATO E.The role of angiogenic growth factors in organogenesis. Int J Dev Biol. 2011; 55(4-5):365-75.

3. GERHARDT H.. VEGF and endothelial guidance in angiogenic sprouting. Organogenesis. 2008; 4: 241-246.

4. TAKAHASHI H., SHIBUYA M. The vascular endothelial growth factor (VEGF)/VEGF receptor system and its role under physiological and pathological conditions. Clin Sci (Lond). 2005 Sep; 109(3):227-41.

5. TISCHER E., GOSPODAROWICZ D., MITCHELL R., SILVA M., SCHILLING J., LAU K., CRISP T., FIDDES J.C., ABRAHAM J.A. Vascular endothelial growth factor: a new member of the platelet-derived growth factor gene family. Biochem Biophys Res Commun. 1989 Dec 29; 165(3):1198-1206.

6. TAMMELA T., ENHOLM B., ALITALO K. AND PAAVONEN K. The biology of vascular endothelial growth factors. Cardiovas Res. 2005; 65: 550-563.

7. DELGHANIAN F., HOJATI Z., KAY M. New insights into VEGF-A alternative splicing: Key regulatory switching in pathological process. Avicenna J Med Biotechnol. 2014 Oct; 6(4):192-9.

8. GIACCA M. Non-redundant functions of the protein isoforms arising from alternative splicing of the VEGF-A pre-mRNA. Transcription 2010; 1(3):149-153.

9. NEUFELD G., COHEN T., GENGRINOVITCH S., AND POLTORAK Z.Vascular endothelial growth factor (VEGF) and its receptors. FASEB J 1999; 13:9-22.

10. POLTORAK Z., COHEN T., SIVAN R., KANDELIS Y., SPIRA G., VLODAVSKY I., KESHET E., AND NEUFELD G. VEGF145, a secreted vascular endothelial growth factor isoform that binds to extracellular matrix. J Biol Chem 1997; 272:7151-7158.

11. LEUNG D.W., CACHIANES G., KUANGW. J., GOEDDEL D. V. and FERRARA N. Vascular endothelial growth factor is a secreted angiogenic mitogen. Science 1989; 246, 1306-1309.

12. KECK P. J., HAUSER S. D., KRIVI G. ET AL. Vascular permeability factor, an endothelial cell mitogen related to PDGF. Science. 1989; 246, 1309-1312.

13. CONNOLLY, D. T., HEUVELMAN, D. M., NELSON, R. et al. Tumor vascular permeability factor stimulates endothelial cell growth and angiogenesis. J. Clin. Invest. 1989; 84, 1470-1478.

14. FERRARA N. AND HENZEL W. J. Pituitary follicular cells secrete a novel heparin-binding growth factor specific for vascular endothelial cells. Biochem. Biophys. Res. Commun. 1989; 161, 851-858.

15. KAJDANIUK D., MAREK B., BORGIEL-MAREK H., KOS-KUDLA B. Vascular endothelial growth factor (VEGF) part 1: in physiology and pathophysiology. Endokrynol Pol 2011; 62(5):444-455.

16. OLOFSSON, B., JELTSCH, M., ERIKSSON, U. AND ALITALO, K. Current biology of VEGF-B and VEGF-C. Curr. Opin. Biotechnol. 1999; 10, 528-535.

17. ORTEGA N., HUTCHINGS H., AND PLOUET J. Signal relays in the VEGF system. Front Biosci 1999; 4:141-152.

18. WALTENBERGER J, CLAESSON-WELSH L, SIEGBAHN A, SHIBUYA M, and HELDIN CH Different signal transduction properties of KDR and Flt1, two receptors for vascular endothelial growth factor. J Biol Chem 1994; 269:26988-26995.

19. NAGY J. A., VASILE E., FENG D. et al. Vascular permeability factor/vascular endothelial growth factor induces lymphangiogenesis as well as angiogenesis. J. Exp. Med. 2002;196, 1497-1506.

20. ACHEN M.G., JELTSCH M., KUKK E., MAKINEN T., VITALI A., WILKS A.F., ALITALO K., AND STACKER S.A. Vascular endothelial growth factor D (VEGF-D) is a ligand for the tyrosine kinases VEGF receptor 2 (Flk1) and VEGF receptor 3 (Flt4). Proc NatlAcad Sci USA. 1999;95:548-553

21. ZARKADA G., HEINOLAINEN K., MAKINEN T., KUBOTA Y., ALITALO K. VEGFR3 does not sustain retinal angiogenesis without VEGFR2. Proc Natl Acad Sci U S A. 2015 Jan 20; 112(3):761-6.

22. FUKUMURA, D., XAVIER, R., SUGIURA, T. et al. Tumor induction of VEGF promoter activity in stromal cells. Cell. 1998; 94, 715-725.

23. ZANG J., LI C., ZHAO L.N., SHI M., ZHOU Y.C., WANG J.H., LI X. Prognostic value of vascular endothelial growth factor in patients with head and neck cancer: A meta-analysis. Head Neck. 2013 Oct; 35(10):1507-14.

24. ANDISHEH-TADBIR A., HAMZAVI M., REZVANI G., ASHRAF M.J., FATTAHI M.J., KHADEMI B., KAMALI F. Tissue expression, serum and salivary levels of vascular endothelial growth factor in patients with HNSCC. Braz J Otorhinolaryngol. 2014 Nov-Dec; 80(6):503-7.

25. LUO H., LI J., YANG T., WANG J. Expression and significance of VEGF-C and VEGF-D in differentiated thyroid carcinoma. Lin Chung Er Bi Yan Hou Tou Jing Wai Ke Za Zhi. 2009 Jun; 23(12):531-4.

26. LIU S.G., YUAN S.H., WU H.Y., LIU J., HUANG C.S. The Clinical Research of Serum VEGF, TGF- $\beta 1$, and Endostatin in Non-small Cell Lung Cancer. Cell Biochem Biophys. 2014 Dec 30. [Epub ahead of print]

27. FU Z.Z., SUN X.D., LI P., ZHANG Z., LI G.Z., GU T., SHAO S.S. Relationship between serum VEGF level and radiosensitivity of patients with nonsmall cell lung cancer among asians: a meta-analysis. DNA Cell Biol. 2014 Jul; 33(7):426-37.

28. LIU G., XU S., JIAO F., REN T., LI Q. Vascular endothelial growth factor B coordinates metastasis of non-small cell lung cancer. Tumour Biol. 2015 Mar; 36(3):2185-91

29. JIANG H., SHAO W., ZHAO W. VEGF-C in non-small cell lung cancer: meta-analysis. Clin Chim Acta. 2014 Jan 1; 427:94-9.

30. SRABOVIC N., MUJAGIC Z., MUJANOVIC-MUSTEDANAGIC J., SOFTIC A., MUMINOVIC Z., RIFATBEGOVIC A., BEGIC L. Vascular endothelial growth factor receptor-1 expression in breast cancer and its correlation to vascular endothelial growth factor A.Int J Breast Cancer. 2013; 2013:746-749. 
31. ZHANG F., LI C., LIU H., WANG Y., CHEN Y., WU X. The functional proteomics analysis of VEGF-treated human epithelial ovarian cancer cells. Tumour Biol. 2014 Dec; 35(12):12379-87.

32. WANG H., HUANG X., ZHANG J., SHAO N., CHEN L.O., MA D., JI C. The expression of VEGF and Dll4/Notch pathway molecules in ovarian cancer. Clin Chim Acta. 2014 Sep 25; 436:243-8.

33. WIMBERGER P., CHEBOUTI I., KASIMIR-BAUER S., LACHMANN R., KUHLISCH E., KIMMIG R., SÜLEYMAN E., KUHLMANN J.D. Explorative investigation of vascular endothelial growth factor receptor expression in primary ovarian cancer and its clinical relevance. Gynecol Oncol. 2014 Jun; 133(3):467-72.

34. MANDIC A., USAJ KNEZEVIC S., KAPICL IVKOVIC T. Tissue expression of VEGF in cervical intraepithelial neoplasia and cervical cancer. J BUON. 2014 Oct-Dec; 19(4):958-64.

35. DEMEI M., XIANGXIN L., YONGPING X., YONGXIA Y., YUNHAI Y., LIN Z. Vascular endothelial growth factor C expression is closely correlated with lymph node recurrence and poor prognosis in patients with early stage cervical cancer. J Int Med Res. 2013 Oct; 41(5):1541-9.

36. WANG J., TAYLOR A., SHOWEIL R., TRIVEDI P., HORIMOTO Y., BAGWAN I., EWINGTON L., LAM E.W., EL-BAHRAWY M.A. Expression profiling and significance of VEGF-A, VEGFR2, VEGFR3 and related proteins in endometrial carcinoma. Cytokine. 2014 Aug; 68(2):94-100.

37. ZHUANG Y., WEI M. Impact of vascular endothelial growth factor expression on overall survival in patients with osteosarcoma: a meta-analysis. Tumour Biol. 2014 Mar; 35(3):1745-9.

38. YU X.W., WU T.Y., YI X., REN W.P., ZHOU Z.B., SUN Y.Q., ZHANG C.Q. Prognostic significance of VEGF expression in osteosarcoma: a meta-analysis. Tumour Biol. 2014 Jan; 35(1):155-60.

39. WOOLLARD D.J., OPESKIN K., COSO S., WU D., BALDWIN M.E., WILLIAMS E.D. Differential expression of VEGF ligands and receptors in prostate cancer.Prostate. 2013 May; 73(6):563-72.

40. KOPPARAPU P.K., BOORJIAN S.A., ROBINSON B.D., DOWNES M., GUDAS L.J., MONGAN N.P., PERSSON J.L. Expression of VEGF and its receptors VEGFR1/VEGFR2 is associated with invasiveness of bladder cancer. Anticancer Res. 2013 Jun; 33(6):2381-90.

41. SUI L., LIU K., SHEN W., ZHANG L. Relationships between VEGF protein expression and pathological characteristics of diffuse large B cell lymphoma: a meta-analysis. Tumour Biol. 2014 Sep; 35(9):9085-93.

42. KINOSHITA S., KASE S., ANDO R., DONG Z., FUKUHARA J., DONG Y., INAFUKU S., NODA K., NODA M., KANDA A., ISHIDA S. Expression of vascular endothelial growth factor in human ocular adnexal lymphoma. Invest Ophthalmol Vis Sci. 2014 May 13; 55(6):3461-7.

43. ZHANG Y.H., DIAO L., YANG Q., DUO J., LIU Y.X., LIU S.X., YAO X. Expression of VEGFR-2 and VEGFR-3 in papillary renal cell carcinoma and their relationship with prognosis. Zhonghua Zhong Liu Za Zhi. 2010 Oct; 32(10):752-6.

44. ZHAO S.F., YANG X.D., LU M.X., SUN G.W., WANG Y.X., ZHANG Y.K., PU Y.M., TANG E.Y. Prognostic significance of VEGF immunohistochemical expression in oral cancer: a meta-analysis of the literature. Tumour Biol. 2013 Oct; 34(5):3165-71.

45. YANASE M., KATO K., YOSHIZAWA K., NOGUCHI N., KITAHARA H., NAKAMURA H. Prognostic value of vascular endothelial growth factors $A$ and $C$ in oral squamous cell carcinoma. J Oral Pathol Med. 2014 Aug; 43(7):514-20.

46. AGGARWAL S., DEVARAJA K., SHARMA S.C., DAS S.N. Expression of vascular endothelial growth factor (VEGF) in patients with oral squamous cell carcinoma and its clinical significance. Clin Chim Acta. 2014 Sep 25; 436:35-40.

47. LI J.D., LIANG R.Y., ZHAO Y.P., XU Y.L. Correlation analysis of VEGF and PTEN expression in gingival carcinoma. Shanghai Kou Qiang Yi Xue. 2014 Oct; 23(5):619-23.

48. OMOTO I., MATSUMOTO M., OKUMURA H., UCHIKADO Y., SETOYAMA T., KITA Y., OWAKI T., KIJIMA Y., SHINCHI H., ISHIGAMI S., UENO S., NATSUGOE S. Expression of vascular endothelial growth factor-C and vascular endothelial growth factor receptor-3 in esophageal squamous cell carcinoma. Oncol Lett. 2014 Apr; 7(4):1027-1032.

49. Yang Z, Wang YG, Su K. VEGF-C and VEGF-D expression and its correlation with lymph node metastasis in esophageal squamous cell cancer tissue. Asian Pac J Cancer Prev. 2015; 16(1):271-4.

50. SU C.M., SU Y.H., CHIU C.F., CHANG Y.W., HONG CC, YU Y.H., HO Y.S., WU C.H., YEN C.S., SU J.L. Vascular endothelial growth factor-C upregulates cortactin and promotes metastasis of esophageal squamous cell carcinoma. Ann Surg Oncol. 2014 Dec; 21 Suppl 4:S767-75.

51. XU X.L., LING Z.Q., CHEN W., XU Y.P., MAO W.M. The overexpression of VEGF in esophageal cancer is associated with a more advanced TMN stage: a meta-analysis. Cancer Biomark. 2013;13(2):105-13.

52. HOU X., WEI J.C., FU J.H., WANG X., LUO R.Z., HE J.H., ZHANG L.J., LIN P., YANG H.X. Vascular Endothelial Growth Factor is a Useful Predictor of Postoperative Distant Metastasis and Survival Prognosis in Esophageal Squamous Cell Carcinoma. Ann Surg Oncol. 2015 Feb 5 [Epub ahead of print].

53. BLANK S., DECK C., DREIKHAUSEN L., WEICHERT W., GIESE N., FALK C., SCHMIDT T., OTT K. Angiogenic and growth factors in gastric cancer. J Surg Res. 2015 Apr; 194(2):420-9.

54. WANG L., LI H.G., WEN J.M., PENG T.S., ZENG H., WANG L.Y. Expression of CD44v3, erythropoietin and VEGF-C in gastric adenocarcinomas: correlations with clinicopathological features. Tumori. 2014 May-Jun; 100(3):321-7.

55. CAO W., FAN R., YANG W., WU Y.VEGF-C expression is associated with the poor survival in gastric cancer tissue. Tumour Biol. 2014 Apr; 35(4):3377-83.

56. PENG L., ZHAN P., ZHOU Y., FANG W., ZHAO P., ZHENG Y., XU N. Prognostic significance of vascular endothelial growth factor immunohistochemical expression in gastric cancer: a meta-analysis. Mol Biol Rep. 2012 Oct; 39(10):9473-84.

57. JI Y.N., WANG Q., LI Y., WANG Z. Prognostic value of vascular endothelial growth factor A expression in gastric cancer: a meta-analysis. Tumour Biol. 2014 Mar; 35(3):2787-93. 
58. WANG Y., YAO X., GE J., HU F., ZHAO Y. Can vascular endothelial growth factor and microvessel density be used as prognostic biomarkers for colorectal cancer? A systematic review and meta-analysis. ScientificWorld Journal. 2014; 2014:102736.

59. BEŞTAŞ R., KAPLAN M.A., IŞIKDOĞAN A. The correlation between serum VEGF levels and known prognostic risk factors in colorectal carcinoma. Hepatogastroenterology. 2014 Mar-Apr; 61(130):267-71.

60. ARAÚJO R.F. JR, LIRA G.A., VILAÇA J.A., GUEDES H.G., LEITÃO M.C., LUCENA H.F., RAMOS C.C. Prognostic and diagnostic implications of MMP-2, MMP-9, and VEGF- $\alpha$ expressions in colorectal cancer. Pathol Res Pract. 2015 Jan; 211(1):71-7.

61. GOOS J.A., DE CUBA E.M., COUPÉ V.M., DIOSDADO B., DELIS-VAN DIEMEN P.M., KARGA C., BELIËN J.A., MENKE-VAN DER HOUVEN VAN OORDT C.W., GELDOF A.A., MEIJER G.A.,HOEKSTRA O.S., FIJNEMAN R.J.; THE DECODE PET GROUP. Glucose transporter 1 (SLC2A1) and vascular endothelial growth factor A (VEGFA) predict survival after resection of colorectal cancer liver metastasis. Ann Surg. 2015 Jan 5. [Epub ahead of print]

62. XU C.J., XU F. MMP-11 and VEGF-C expression correlate with clinical features of colorectal adenocarcinoma. Int J Clin Exp Med. 2014 Sep 15; 7(9):2883-8.

63. MARTINS S.F., GARCIA E.A., LUZ M.A., PARDAL F., RODRIGUES M., FILHO A.L. Clinicopathological correlation and prognostic significance of VEGF-A, VEGF-C, VEGFR-2 and VEGFR-3 expression in colorectal cancer.Cancer Genomics Proteomics. 2013 Mar-Apr; 10(2):55-67.

64. HSIEH M.C., HSU H.T., HSIAO P.C., YANG S.F., YEH C.B., BIEN M.Y., LIN C.H., CHIEN M.H. Role of VEGF-C gene polymorphisms in susceptibility to hepatocellular carcinoma and its pathological development.J Clin Lab Anal. 2014 May; 28(3):237-44.

65. LETELIER P., GARCIA P., LEAL P., ILI C., BUCHEGGER K., RIQUELME I., SANDOVAL A., TAPIA O., ROA J.C. Immunohistochemical expression of vascular endothelial growth factor $A$ in advanced gallbladder carcinoma. Appl Immunohistochem Mol Morphol. 2014 Aug; 22(7):530-6.

66. LIN W., JIANG L., CHEN Y., SHE F., HAN S., ZHU J., ZHOU L., TANG N., WANG X., LI X. Vascular endothelial growth factor-D promotes growth, lymphangiogenesis and lymphatic metastasis in gallbladder cancer. Cancer Lett. 2012 Jan 28 ; 314(2):127-36.

67. SIPOS B., KLAPPER W., KRUSE M.L., KALTHOFF H., KERJASCHKI D., KLÖPPEL G. Expression of lymphangiogenic factors and evidence of intratumoral lymphangiogenesis in pancreatic endocrine tumors. Am J Pathol. 2004 Oct; 165(4):1187-97.

68. HANSEL D.E., RAHMAN A., HERMANS J., DE KRIJGER R.R., ASHFAQ R., YEO C.J., CAMERON J.L., MAITRA A. Liver metastases arising from well-differentiated pancreatic endocrine neoplasms demonstrate increased VEGF-C expression. Mod Pathol. 2003 Jul; 16(7):652-9.

69. REID M.D., CHOI H., BALCI S., AKKAS G., ADSAY V. Serous cystic neoplasms of the pancreas: clinicopathologic and molecular characteristics. Semin Diagn Pathol. 2014 Nov; 31(6):475-83.

70. YIP-SCHNEIDER M.T., WU H., DUMAS R.P. HANCOCK B.A., AGARAM N., RADOVICH M., SCHMIDT C.M. Vascular endothelial growth factor, a novel and highly accurate pancreatic fluid biomarker for serous pancreatic cysts. J Am Coll Surg. 2014 Apr; 218(4):608-17.

71. LISZKA Ł., PAJĄK J., GOŁKA D. Serous neoplasms of the pancreas share many, but not all aspects of their microvascular and angiogenic profile with low-grade clear cell renal cell carcinomas. Pathol Res Pract. 2014 Dec; 210(12):901-8.

72. AI K.X., LU L.Y., HUANG X.Y., CHEN W., ZHANG H.Z. Prognostic significance of S100A4 and vascular endothelial growth factor expression in pancreatic cancer. World J Gastroenterol. 2008 Mar 28; 14(12):1931-5.

73. VON MARSCHALL Z., CRAMER T., HÖCKER M., BURDE R., PLATH T., SCHIRNER M., HEIDENREICH R., BREIER G., RIECKEN E.O., WIEDENMANN B., ROSEWICZ S. De novo expression of vascular endothelial growth factor in human pancreatic cancer: evidence for an autocrine mitogenic loop. Gastroenterology. 2000 Nov; 119(5):1358-72.

74. SEO Y., BABA H., FUKUDA T., TAKASHIMA M., SUGIMACHI K. High expression of vascular endothelial growth factor is associated with liver metastasis and a poor prognosis for patients with ductal pancreatic adenocarcinoma. Cancer. 2000 May $15 ; \mathbf{8 8}(10): 2239-45$.

75. LIANG Q.L., WANG B.R., CHEN G.Q., LI G.H., XU Y.Y. Clinical significance of vascular endothelial growth factor and connexin43 for predicting pancreatic cancerclinicopathologic parameters. Med Oncol. 2010 Dec; 27(4):1164-70.

76. ZORGETTO V.A., SILVEIRA G.G., OLIVEIRA-COSTA J.P., SOAVE D.F., SOARES F.A., RIBEIRO-SILVA A. The relationship between lymphatic vascular density and vascular endothelial growth factor A (VEGF-A)expression with clinicalpathological features and survival in pancreatic adenocarcinomas. Diagn Pathol. 2013 Oct 18; 8:170.

77. GEORGIADOU D., SERGENTANIS T.N., SAKELlARIOU S., FILIPPAKIS G.M., ZAGOURI F., VLACHODIMITROPOUlOS D., PSALTOPOUlOU T., LAZARIS A.C., PATSOURIS E., ZOGRAFOS G.C.VEGF and Id-1 in pancreatic adenocarcinoma: prognostic significance and impact on angiogenesis. Eur J Surg Oncol. 2014 Oct; 40(10):1331-7.

78. SMITH R.A., TANG J., TUDUR-SMITH C., NEOPTOLEMOS J.P., GHANEH P. Meta-analysis of immunohistochemical prognostic markers in resected pancreatic cancer. Br J Cancer. 2011 Apr 26; 104(9):1440-51.

79. PATSOURAS D., PAPAXOINIS K., KOSTAKIS A., SAFIOLEAS M.C., LAZARIS A.C., NICOLOPOULOU-STAMATI P. Fibroblast activation protein and its prognostic significance in correlation with vascular endothelial growth factor in pancreatic adenocarcinoma. Mol Med Rep. 2015Jun; 11(6):4585-90

80. SIPOS B., WEBER D., UNGEFROREN H., KALTHOFF H., ZÜHLSDORFF A., LUTHER C., TÖRÖK V., KLÖPPEL G. Vascular endothelial growth factor mediated angiogenic potential of pancreatic ductal carcinomas enhanced by hypoxia: an in vitro and in vivo study. Int J Cancer. 2002 Dec 20; 102(6):592-600. 
81. ANDREOZZI M., QUAGLIATA L., GSPONER J.R., RUIZ C., VUAROQUEAUX V., EPPENBERGER-CASTORI S., TORNILLO L., TERRACCIANO L.M. VEGFA gene locus analysis across 80 human tumour types reveals gene amplification in several neoplastic entities. Angiogenesis. $2014 \mathrm{Jul}$; 17(3):519-27.

82. TANG R.F., WANG S.X., PENG L., WANG S.X., ZHANG M., LI Z.F., ZHANG Z.M., XIAO Y., ZHANG F.R. Expression of vascular endothelial growth factors $A$ and $C$ in human pancreatic cancer. World J Gastroenterol. 2006 Jan 14; 12(2):280-6.

83. DOI Y., YASHIRO M., YAMADA N., AMANO R., NODA S., HIRAKAWA K. VEGF-A/VEGFR-2 signaling plays an important role for the motility of pancreas cancer cells. Ann Surg Oncol. 2012 Aug; 19(8):2733-43.

84. DOI Y., YASHIRO M., YAMADA N., AMANO R., OHIRA G., KOMOTO M., NODA S., KASHIWAGI S., KATO Y., FUYUHIRO Y., HIRAKAWA K. Significance of phospho-vascular endothelial growth factor receptor-2 expression in pancreatic cancer. Cancer Sci. 2010 Jun; 101(6):1529-35.

85. KNOLL M.R., RUDNITZKI D., STURM J., MANEGOLD B.C., POST S., JAEGER T.M. Correlation of postoperative survival and angiogenic growth factors in pancreatic carcinoma. Hepatogastroenterology. 2001 Jul-Aug; 48(40):1162-5.

86. TANG R.F., ITAKURA J., AIKAWA T., MATSUDA K., FUJII H., KORC M., MATSUMOTO Y. Overexpression of lymphangiogenic growth factor VEGF-C in human pancreatic cancer. Pancreas. 2001 Apr; 22(3):285-92.

87. SCHNEIDER M., BÜCHLER P., GIESE N., GIESE T., WILTING J., BÜCHLER M.W., FRIESS H. Role of lymphangiogenesis and lymphangiogenic factors during pancreatic cancer progression and lymphatic spread. Int J Oncol. 2006 Apr; 28(4):883-90.

88. CHENG P., JIN G., HU X., SHI M., ZHANG Y., LIU R., ZHOU Y., SHAO C., ZHENG J., ZHU M. Analysis of tumor-induced lymphangiogenesis and lymphatic vessel invasion of pancreatic carcinoma in the peripheral nerve plexus. Cancer Sci. 2012 Oct; 103(10):1756-63.

89. LI K., LI M.J., HE T., ZHENG Z., ZHENG X.L., QU B.H., WANG Y., DUAN X., ZHENG Y.J. Expression of vascular endothelial growth factor $C$ in pancreatic cancer and its effect upon lymph node metastasis. Zhonghua Yi Xue Za Zhi. 2009 Sep 15; 89(34):2386-90.

90. VON MARSCHALl Z., SCHOLZ A., STACKER S.A., ACHEN M.G., JACKSON D.G., ALVES F., SCHIRNER M., HABEREY M., THIERAUCH K.H., WIEDENMANN B., ROSEWICZ S. Vascular endothelial growth factor-D induces lymphangiogenesis and lymphatic metastasis in models of ductal pancreatic cancer. Int J Oncol. 2005 Sep; 27(3):669-79.

91. KURAHARA H., TAKAO S., MAEMURA K., SHINCHI H., NATSUGOE S., AIKOU T. Impact of vascular endothelial growth factor-C and $-D$ expression in human pancreatic cancer: its relationship to lymph node metastasis. Clin Cancer Res. 2004 Dec 15; 10(24):8413-20.

92. WEY J.S., FAN F., GRAY M.J., BAUER T.W., MCCARTY M.F., SOMCIO R., LIU W., EVANS D.B., WU Y., HICKLIN D.J., ELLIS L.M. Vascular endothelial growth factor receptor-1 promotes migration and invasion in pancreatic carcinoma cell lines.Cancer. $2005 \mathrm{Jul}$ 15; 104(2):427-38.

93. YANG A.D., CAMP E.R., FAN F., SHEN L., GRAY M.J., LIU W., SOMCIO R., BAUER T.W., WU Y., HICKLIN D.J., ELLIS L.M.. Vascular endothelial growth factor receptor-1 activation mediates epithelial to mesenchymal transition in human pancreatic carcinoma cells. Cancer Res. 2006 Jan 1; 66(1):46-51.

94. CHUNG G.G., YOON H.H., ZERKOWSKI M.P., GHOSH S., THOMAS L., HARIGOPAL M., CHARETTE L.A., SALEM R.R., CAMP R.L., RIMM D.L., BURTNESS B.A. Vascular endothelial growth factor, FLT-1, and FLK-1 analysis in a pancreatic cancer tissue microarray. Cancer. 2006 Apr 15; 106(8):1677-84.

95. ANGELESCU R., BURADA F., ANGELESCU C., GHEONEA D.I., IORDACHE S., MIXICH F., IOANA M., SĂFTOIU A. Expression of vascular endothelial growth factor and epidermal growth factor receptor in pancreatic ductal adenocarcinomas, neuroendocrine tumours and chronic pancreatitis. Endosc Ultrasound. 2013 Apr; 2(2):86-91.

Received April 18, 2015 